\title{
Article
}

\section{The 'Most Distinguished Envoy of Peace': Averell Harriman and the Vietnam War in the Johnson Years}

\author{
Colman, Jonathan
}

Available at http://clok.uclan.ac.uk/12005/

Colman, Jonathan ORCID: 0000-0003-1223-9679 (2015) The 'Most

Distinguished Envoy of Peace': Averell Harriman and the Vietnam War in the Johnson Years. International History Review, 38 (1). pp. 66-87. ISSN 0707-5332

It is advisable to refer to the publisher's version if you intend to cite from the work. http://dx.doi.org/10.1080/07075332.2015.1007514

For more information about UCLan's research in this area go to http://www.uclan.ac.uk/researchgroups/ and search for < name of research Group>.

For information about Research generally at UCLan please go to http://www.uclan.ac.uk/research/

All outputs in CLoK are protected by Intellectual Property Rights law, including Copyright law. Copyright, IPR and Moral Rights for the works on this site are retained by the individual authors and/or other copyright owners. Terms and conditions for use of this material are defined in the policies page.

\section{CLoK}

Central Lancashire online Knowledge www.clok.uclan.ac.uk

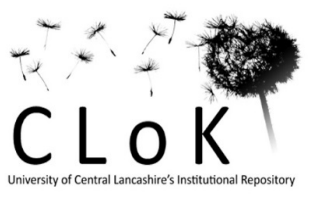




\title{
The 'most distinguished envoy of peace': Averell Harriman and the Vietnam War in the Johnson Years
}

\author{
The International History Review \\ http://www.tandfonline.com/doi/full/10.1080/07075332.2015.1007514
}

Author's Accepted Manuscript

\section{Jonathan Colman \\ University of Central Lancashire, Preston, England jcolman@uclan.ac.uk}

Victory of course proved elusive for the United States in Vietnam after assuming a combat role in 1965 under President Lyndon B. Johnson. While the war was underway, elder statesman Averell Harriman took the leading role in the efforts of the State Department to negotiate an end to the war - National Security Adviser McGeorge Bundy described him as the 'most distinguished envoy of peace'. ${ }^{1}$ Harriman was at the forefront of a number of initiatives, pursuing them with exemplary energy and commitment. Although still a firm advocate of the general principle of 'containment', he felt that the fight for South Vietnam was not worth the damage to American national unity and international prestige. Harriman sought a settlement based on the restoration of the Geneva Accords of 1954, in the context of a broader vision of a non-aligned and economically developed Indochina with underpinned by security guarantees from the United States and other major powers. Drawing on his early diplomatic experiences, Harriman strove persistently to engage Soviet help, but the commitment from Moscow was erratic and ultimately unproductive. While the Soviets sought to continue the post-Cuban Missile Crisis détente and feared the Vietnam War getting out of hand, the likelihood of Soviet assistance was compromised by the intensifying rivalry with communist China. Supporting wars of national liberation was an earnest of ideological integrity in the battle for influence in the communist world.

Harriman experienced only limited progress. When he left office at the beginning of 1969, he was embittered and resentful about the opportunities for peace that Johnson and some of his advisers seemed to have squandered, but it has emerged from communist records that attitudes in Hanoi were at least as much a sticking point as attitudes in the White House. Although North Vietnam agreed to direct contacts in 1968, the intention was to win international sympathy for their cause and exploit public opinion in the United States. The article draws upon Harriman's personal papers as well as transcripts of presidential telephone conversations, White House and State Department memoranda, and CIA assessments. Some of the most recent secondary research is used, too, to shed light on communist attitudes and policies and to highlight some of the latest interpretations of the Vietnam War. The article provides an up-to-date account of the contributions to the diplomacy of Vietnam from one of the most eminent figures in US Cold War diplomacy, adding a new perspective to American involvement in Southeast Asia.

\footnotetext{
${ }^{1}$ Bundy to Johnson, 2 December 1965, Foreign Relations of the United States (FRUS) 1964-1968 III Vietnam June-December 1965 (Washington DC: USGPO, 1996), p.596.
} 
There are two broad categories of interpretation concerning US intervention in Vietnam in the 1960s. ${ }^{2}$ Orthodox perspectives emerged from the arguments of contemporary journalists, academics and other critics, and argue that the United States should not have escalated its commitment in Vietnam as the 'domino theory' was flawed, and that US 'credibility' in the Cold War would have been better served by more nuanced assessment of American interests than by fighting in Vietnam. US policymakers are charged too with the failure to take up promising opportunities to negotiate an early end to the war. Historian Fredrik Logevall endorsed a State Department analysis from 1965 which asked: 'Has Hanoi shown any [serious] interest in negotiations? Yes, repeatedly.' He added that 'The same thing could never have been said of the United States. ${ }^{3}$ Revisionist arguments began to emerge in force in the 1980s, and maintained that US interests did require a forceful stance against the spread of communism in Southeast Asia. However, the war was not prosecuted with sufficient skill and force, and so a viable opportunity to secure victory was lost. Revisionist writers tend also to discount the opportunity for constructive negotiations. Mark Moyar, for example, has maintained that 'Evidence from the Communist side ... reveals North Vietnam's complete unwillingness to negotiate' a 'US withdrawal from Vietnam that would have preserved a non-Communist South Vietnam for years to come'. ${ }^{4}$ This article maintains, in line with orthodox arguments, that the Johnson administration entertained few real hopes of a peaceful settlement of the war, and evinced a commitment to negotiations largely to legitimise the war effort. At the same time, it is also argued - in keeping with the revisionist perspective - that the North Vietnamese set little store by a negotiated settlement, feeling confident that they could achieve their goals by military means.

\section{Harriman's Background}

Born into great wealth in New York City in 1891 and educated at Groton and Yale, Harriman worked initially in business and finance, including negotiating mineral concessions with top Soviet officials in the 'New Economic Policy' era of the 1920s. ${ }^{5}$ He began his career in public service in 1933 with the Roosevelt government to implement New Deal policies to support US business. Foreign affairs experience

\footnotetext{
2 See John Dumbrell, Rethinking the Vietnam War (Basingstoke: Palgrave Macmillan, 2012), pp.13-21, for a cogent account of the chief interpretations.

${ }^{3}$ Fredrik Logevall, Choosing War: The Lost Chance for Peace and the Escalation of the War in Vietnam (Berkeley: University of California Press, 1999), xx.

${ }^{4}$ Mark Moyar, Triumph Forsaken: The Vietnam War, 1954-1965 (Cambridge: Cambridge University Press, 2006), xxi.

${ }^{5}$ Accounts of Harriman's life and career include Rudy Abramson, Spanning the Century: The Life of W. Averell Harriman, 1891-1986 (New York: Morrow, 1992); Frank Costigliola, Roosevelt’s Lost Alliances: How Personal Politics Helped to Start the Cold War (Princeton: Princeton University Press, 2013); Martin Folly, 'W. Averell Harriman, 1946', in Alison Holmes and J. Simon Rofe (eds), The Embassy in Grosvenor Square: American Ambassadors to the United Kingdom, 1938-2008 (Basingstoke: Palgrave, 2012), pp.64-84; Walter L. Hixson, 'Averell Harriman', in vol. 2 of Bruce W. Jentleson and Thomas G. Paterson (eds), Encyclopedia of US Foreign Relations (New York and Oxford: Oxford University Press, 1997), pp.283-85; Walter Isaacson and Evan Thomas, The Wise Men: Six Friends and the World They Made (New York: Simon and Schuster, 1992); David Mayers, The Ambassadors and America's Soviet Policy (New York and Oxford: Oxford University Press, 1995), pp.146-63; Lynne Olson, Citizens of London: The Americans Who Stood with Britain in its Darkest, Finest Hour (New York: Presidio Press, 2013); G. Kent Sieg, 'W. Averell Harriman, Henry Cabot Lodge and the Quest for Peace in Vietnam’, Peace and Change, 20:2 (April 1995), pp.237-249. Chester L. Cooper, In the Shadows of History: 50 Years Behind the Scenes of Cold War Diplomacy (Amherst: Prometheus, 2005), pp.235-38, is especially good on Harriman's somewhat dour personality.
} 
included administering Lend-Lease aid in London 1941-43 and then serving as Ambassador to the Soviet Union until 1945. Harriman has been criticised in the latter role for his limited engagement with the bureaucratic grind of diplomacy and with the ideological subtleties of the Soviet system, ${ }^{6}$ but he succeeded all the same in securing regular access to Stalin and other leading officials - not least because the Soviet leader felt that Harriman had in the 1920s tried 'to help the Soviet people'. ${ }^{7}$ Harriman was justified in a 1968 statement that 'Not many people have had experience in dealing with senior Russians; no-one saw Stalin more than I'. ${ }^{8}$ The Soviet misuse of LendLease assistance and Moscow's brutal attitude to the Warsaw uprising of 1944 led him to advocate a tougher stance towards the Soviet Union, making him an early advocate of containment. ${ }^{9}$ In April 1945 he maintained that to avoid 'a world dominated by Soviet policies we must abandon our conciliatory policies and put our reliance on four square policies' ${ }^{10}$ Dean Acheson suggested that Harriman was 'ferocious about the Rouskis' and wanted to 'beat them with any stick he could find'. ${ }^{11}$ Yet while Harriman was no admirer of communism he felt that it was possible to put ideological differences to one side to build a pragmatic relationship with Moscow based on shared interests. ${ }^{12}$ Later, as Ambassador in London and then Secretary of Commerce (dealing with the Marshall Plan) under Truman, Harriman furthered American policies in the developing Cold War.

After time as Governor of New York, and after he had engaged in some cajoling, Harriman served in the John F. Kennedy administration, in the roles of Ambassador at Large, Assistant Secretary of State for East Asian and Pacific Affairs and then Undersecretary of State for Political Affairs. ${ }^{13}$ The 'Governor' led the US delegation in talks with the Soviets in Geneva over Laos. ${ }^{14} \mathrm{He}$ regarded the agreement, concluded in 1962 after lengthy talks, providing for Laotian neutrality as an example of how the Soviet Union and the United States could work constructively together in Southeast Asia and beyond. In particular, he believed that he had a 'gentleman's agreement' with Soviet Foreign Minister Georgi Pushkin to the effect that foreign troops would respect Laotian neutrality, ${ }^{15}$ but he never blamed the Soviets for the extensive North Vietnamese violations that were evident from the outset. Harriman further demonstrated his negotiating skills with the Nuclear Test Ban Treaty of 1963. This was the first arms control agreement of the Cold War and it

\footnotetext{
${ }^{6}$ Olson, Citizens of London, p.336.

${ }^{7}$ Memorandum of conversation, 15 July 1965, FRUS 1964-1968 III, pp.150-51.

${ }^{8}$ Harriman-Trewhitt telephone conversation, 10 April 1968, Special Files Public Service, JFK-LBJ, Chron File April 1968, Box 571, Averell Harriman Papers (AHP), Library of Congress.

${ }^{9}$ Mayers, The Ambassadors, p.146.

${ }^{10}$ Quoted in Wilson D. Miscamble, From Roosevelt to Truman: Potsdam, Hiroshima, and the Cold War (New York: Cambridge, 2007), pp.82-83.

${ }^{11}$ Quoted in Robert L. Beisner, Dean Acheson: A Life in the Cold War (New York: Oxford, 2009), p.29.

${ }^{12}$ Quoted in Isaacson and Thomas, The Wise Men, pp.263-64.

${ }^{13}$ Abramson, Spanning the Century, p.631. See Robert Dallek, Camelot's Court: Inside the Kennedy White House (New York: Harper Collins, 2013), p.193, on Harriman's joining the Kennedy administration.

${ }^{14}$ Recent literature on Laos includes Seth Jacobs, The Universe Unraveling: American Foreign Policy in Cold War Laos (Ithaca: Cornell University Press, 2012); and two books by William Rust: Before the Quagmire: American Intervention in Laos, 1954-1961 (Lexington: University Press of Kentucky, 2012), and So Much to Lose: John F. Kennedy and American Policy in Laos ((Lexington: University Press of Kentucky, 2014).

${ }^{15}$ Cooper, In the Shadows of History, p.190; Pushkin-Harriman understanding, FRUS 1964-1968 XXVIII Laos (1998), p.566.
} 
contributed to non-proliferation. As well as representing another success in multilateral negotiations, the agreement was an example of Harriman furthering Soviet-American cooperation, although it fell short of the Administration's hope for Soviet guarantees against a Chinese nuclear capability. ${ }^{16}$

So far as Vietnam was concerned, Harriman was authorised to talk privately with the North Vietnamese as the Laos negotiations concluded, but in doing so he met with no indication of willingness to compromise. ${ }^{17}$ Harriman soon grew concerned about Saigon's failure to win popular support in the face of the mounting communist counterinsurgency, feeling that the American commitment of advisers and material aid would be wasted in the absence of an effective government in South Vietnam. He shared responsibility with Roger Hilsman, Michael Forrestal and George Ball for the infamous telegram to the Saigon embassy on 24 August 1963 suggesting that the United States would stand aside in the even of an attempt to overthrow President Ngo Dinh Diem and his brother Nhu. Harriman was the strongest advocate of promoting a coup in the administration, ${ }^{18}$ although recent research has indicated that responsibility for the demise of Diem and his brother was well-diffused throughout the administration, so that the circle of culpability included President Kennedy. ${ }^{19}$ All the same, Harriman and his associates were Washington's prime movers in relation to initiating the coup. They had assumed that Diem and Nhu would suffer a fate no worse than exile or house arrest, so the murder of the two men came as a deep shock. Successive regimes in Saigon failed to establish themselves, in part because the Viet Cong encouraged and exploited the instability by intensifying their guerrilla campaign.

By the time of John F. Kennedy's assassination a few weeks after the South Vietnam coup, there were some 16,000 American 'advisers' in Vietnam, many times the number present since the beginning of 1961. Harriman considered that Kennedy's increasing of the number of US advisers flowed inexorably from the decisions of the Eisenhower administration, ${ }^{20}$ which had supported the French military effort against the communists and then after the Geneva conference of 1954 extended growing support to preserve South Vietnam against the communist insurgency. There is evidence that at the time Harriman supported those decisions. In a 1954 discussion with former Truman officials, he was the most vigorous advocate of intervention, ruing the possibility of 'abandoning the whole of Southeast Asia'. ${ }^{21}$ More than likely Harriman's view derived in large part from the expediency of criticising the Republicans at a time when he felt that the administration might not pursue the commitment Vietnam. Later he would blame the Eisenhower administration for doing the very thing he had advocated, that is, backing the Saigon regime; he would argue

\footnotetext{
${ }^{16}$ Michael Lumbers, Piercing the Bamboo Curtain: Tentative Bridge Building to China during the Johnson Years (Manchester and New York: Manchester University Press, 2008), pp.37-38; Suzanna Schraftstetter and Stephen Twigge, Avoiding Armageddon: Europe, the United States and the Struggle for Nuclear Non-Proliferation (New York: Praeger, 2004), pp.120-21.

${ }^{17}$ Eugenie Blang, Allies at Odds: America, Europe and Vietnam, 1961-1968 (Lanham: Rowman and Littlefield, 2011), pp.16-17; William P. Sullivan, Obbligato: Notes on a Foreign Service Career 19391979 (New York: Norton: 1984), pp.176-78.

${ }^{18}$ Dallek, Camelot's Court, p.402.

${ }^{19}$ State to Embassy in Vietnam, 24 August 1963, FRUS 1961-1963 III Vietnam January-August 1963 (1991), pp.628-29. See John Prados, 'The Diem Coup after 50 Years: John F. Kennedy and South Vietnam', The National Security Archive http://www2.gwu.edu/ nsarchiv/NSAEBB/NSAEBB444/

${ }^{20}$ Henry Brandon, Special Relationships: A Foreign Correspondent's Memoirs from Roosevelt to Reagan (London: Macmillan, 1988), p.193.

${ }^{21}$ Quoted in Isaacson and Thomas, The Wise Men, p.635.
} 
that an irrevocable commitment to Vietnam had been made. Harriman was staunch in his Democratic loyalties, and in his propensity to blame the Republicans. During a Democratic strategy meeting in the 1970s his one-time assistant Chester Cooper suggested that Kennedy and Johnson should be given their share of the blame in relation to Vietnam, to which Harriman replied 'You can be for the Democrats or for God, Chet. If you choose God, you better leave the meeting. ${ }^{22}$ While Harriman exonerated JFK, there have been mixed verdicts of Kennedy's Vietnam policies among historians. Some have argued that by the time he was murdered he had plans to withdraw the US advisers. Others have suggested that he had a firm commitment to containment in Indochina. ${ }^{23}$ No-one can know how Kennedy would have reacted to the deteriorating situation after Diem's overthrow. The best assessment is that Kennedy was ambivalent towards the commitment in Vietnam, and although he did not plan withdrawal, this prospect would - certainly if the situation was relatively stable - have been a real possibility after the 1964 presidential election. ${ }^{24}$

\section{Banished to Africa}

John F. Kennedy had considered the septuagenarian, hard-of-hearing Harriman a little too old for the dynamic and youthful ethos of the New Frontier, but came to appreciate his dedication and his substantial talents as displayed in the Laos and the Test Ban Treaty negotiations. However, Harriman's power waned under Johnson. ${ }^{25}$ The new President, who was never an admirer of 'cloak and dagger' initiatives, abhorred the US role in the anti-Diem coup, ${ }^{26}$ and he resented Harriman's close relationship with political rival Robert F. Kennedy. ${ }^{27}$ Although Johnson retained key Kennedy advisers such as Secretary of Defense Robert S. McNamara, National Security Adviser McGeorge Bundy and Secretary of State Dean Rusk, he sought to limit Harriman's influence, placing him under Secretary of State for African Affairs G. Mennen Williams. Foreign affairs were not Johnson's natural domain, and he had little inherent interest in Africa except so far as events there resonated in the United States. When Harriman appeared to tell the press that Williams would report to him instead of the other way around, Johnson complained to an aide that 'I think you've

\footnotetext{
${ }^{22}$ Cooper, In the Shadows of History, p.235.

${ }^{23}$ Writers favourable to Kennedy include John M. Newman, JFK and Vietnam: Deception, Intrigue and the Struggle for Power (New York: Warner Books, 1992); and Robert McNamara, In Retrospect: The Tragedy and Lessons of Vietnam (New York: Times Books, 1995), while critics include Lawrence Bassett and Stephen Pelz, 'The failed search for victory: Vietnam and the politics of war', in Thomas Paterson (ed.), Kennedy’s Quest for Victory (New York: Oxford University Press, 1989), pp.223-52. ${ }^{24}$ Dumbrell, Rethinking the Vietnam War, pp.35-44.

${ }^{25}$ Michael Beschloss (ed), Reaching for Glory: Lyndon Johnson's Secret White House Tapes, 19641965 (New York: Simon and Schuster, 2001); pp.333, 371; Michael Beschloss (ed), Taking Charge: The Johnson White House Tapes, 1963-64 (New York: Simon and Schuster, 1997), p.145; Freedman, Kennedy's Wars, p.38; editorial note, FRUS 1964-1968 XXXIII Organization and Management of Foreign Policy (2004), p.190; Richard L. Schott and Hamilton, People, Positions and Power: The Political Appointments of Lyndon B. Johnson (Chicago: Chicago University Press, 1984), p.37; Dean Rusk interview I, conducted by Paige E. Mulhollan, 28 July 1969, Lyndon B. Johnson Presidential Library (LBJL).

${ }^{26}$ Lawrence Freedman, Kennedy’s Wars: Berlin, Cuba, Laos and Vietnam (New York: Oxford University Press, 2000), p.401; Cooper, In the Shadows of History, p.266; George C. Herring, LBJ and Vietnam: A Different Kind of War (Austin: University of Texas Press, 1995), p.104; Chester Cooper oral history interview conducted by Paige E. Mulhollan, 9 July 1979, LBJL.

${ }^{27}$ Beschloss, Taking Charge, p.429; Cooper, In the Shadows of History, p.266.
} 
just got to knock Harriman down'. ${ }^{28}$ Nor did Harriman help himself by criticising the appointment of conservative Thomas Mann to head the Alliance for Progress, a Kennedy initiative to help modernise Latin American states. The President complained to Senator William J. Fulbright that if Harriman had 'any differences' with other advisers he should 'express them to them and not be calling around town and talking to other people and drumming up a campaign'. Harriman was 'a nice fellow' but he was - in a damning suggestion - 'old and dead'. ${ }^{29}$

Harriman was touchy about his diminished status in the new administration, ${ }^{30}$ yet served Johnson faithfully and professionally all the same. He had genuine and lasting respect for the President's 'superlative record' on domestic affairs 'which outachieved Roosevelt, Truman and Kennedy put together'. ${ }^{31}$ McGeorge Bundy noted that Harriman was 'fanatically loyal to the President', and sought 'nothing more than to be President Johnson's most effective diplomatic instrument'. ${ }^{32}$ Harriman worked hard to fulfil his African responsibilities, with affairs in the Congo proving especially time-consuming. After gaining independence from Belgium in 1962 the country appeared to be on the verge of tribal civil war. Harriman was aggrieved when at a critical point George Ball was appointed over his head as a troubleshooter. He complained that 'I was told to take care of Africa, and then every important decision is taken out of my hands'. ${ }^{33}$ Harriman did not pursue any radical departures in policy in Africa, seeing the continent in large part through Cold War lenses. He noted with satisfaction in 1964 that 'Not a single new African nation has succumbed to Communist domination'. ${ }^{34}$

\section{Escalation in Vietnam}

Although concerned mainly with African affairs at this stage, Harriman still had some involvement with Southeast Asia, where he proved willing to endorse the use of punitive violence. In a meeting about Laos with Johnson and other advisers in June 1964, he supported an air-strike on a Pathet Lao anti-aircraft battery after the destruction of a US reconnaissance plane. Harriman was probably the most aggressive of those assembled, expressing his determination to 'convey a message' about American resolve to Hanoi. ${ }^{35}$ Laos was an issue of particular sensitivity for Harriman, given his central role in the 1962 settlement. He also endorsed punitive violence in relation to the somewhat ambiguous North Vietnam 'attacks' in the Gulf of Tonkin on the US destroyers Maddox and the C. Turner Joy in August 1964. One writer has suggested that 'American officials engaged in deliberate and repeated deception about what went on in the Gulf in the days surrounding the affair', ${ }^{36}$ but Harriman seems to have overlooked the questionable character of the administration's representations in Congress to obtain the Southeast Asia Resolution. Instead, he noted with satisfaction

\footnotetext{
${ }^{28}$ Robert David Johnson and Kent B. Germany (eds), The Presidential Recordings: Lyndon B. Johnson: Towards the Great Society, IV, February 1 1964- May 311964 (New York: Norton, 2007), p.810, note 25; p.822 (quotation); pp.847, 848.

${ }^{29}$ Beschloss, Taking Charge, pp.401,403.

${ }^{30}$ Cooper, In the Shadows of History, p.266.

${ }^{31}$ General review of last six months, 14 December 1968, Box 558, AHP.

${ }^{32}$ Bundy to Johnson, 21 January 1965, FRUS 1964-1968 XXXIII, p.35.

${ }^{33}$ Quoted in Abramson, Spanning the Century, p.635.

${ }^{34}$ Harriman to Johnson, 28 October 1964, FRUS 1964-1968 XXIV Africa (1999), p.285.

${ }^{35}$ Conference with President Johnson, 8 June 1964, FRUS 1964-1968 XXVIII, p.152.

${ }^{36}$ Logevall, Choosing War, p.196.
} 
that the air-strikes on North Vietnam won 'the respect of many countries by the determination shown, and the acquiescence of others who are reserving judgment'. ${ }^{37}$

Soon after an attack on an American base at Pleiku in February 1965, the administration initiated the sustained 'Rolling Thunder' air campaign and authorised the first wave of US combat troops in Vietnam. Harriman did not play a role in the critical deliberations in Washington in spring 1965 about expanding the US commitment in Vietnam; that task was confined largely to the 'awesome foursome' of Johnson, Rusk, McNamara, and Bundy. ${ }^{38}$ As with Kennedy, Harriman was never inclined to blame Johnson for the Vietnam disaster. The nearest he came to doing so was to suggest that the President had wrongly been 'sold the idea that it was his duty to fight Vietnam through', ${ }^{39}$ by advisers such as Dean Rusk and by the military. ${ }^{40}$ Generally, in committing the United States to a combat role in Vietnam Johnson is seen as having made bad decisions without questioning his underlying assumptions, although it is acknowledged that he had a healthy fear of precipitating the Third World War and that he took advice from a wide range of sources, ${ }^{41}$ beyond just his immediate advisers.

By early 1968 there were over half a million American soldiers in Vietnam. Victory was proving elusive, with the American public losing patience, and the political climate on the US growing increasingly fractured. One of Harriman's concerns as the US fighting role in Vietnam expanded was 'the deep division' that developed 'among the American people'. This fostered an 'attitude of isolationism which would cripple us in dealing with future world problems in other areas'. He was also concerned about

the loss of American prestige ... Before Viet-Nam, the US was the standard bearer of moral principle in world affairs. This was being greatly shattered by Viet-Nam because of the people's misunderstanding of the issues, or perhaps the arrogant manner in which we were going it alone. ${ }^{42}$

As the reality of the United States' open-ended combat commitment in Vietnam set in, the idea of negotiating a peace became all the more attractive to Harriman. He spent less time delineating a possible settlement than he did trying to initiate talks, but the outlines of what he sought are evident from his memoranda and statements. He considered that a restoration of the Geneva Accords of 1954, in conjunction with honouring the Geneva Accords of 1962 in Laos, would provide the best foundation for peace (it seems that he did not advocate holding the elections in Vietnam that were proposed as part of the 1954 settlement). ${ }^{43}$ Harriman also thought beyond the Geneva Accords, seeing the potential of Indochina as a non-aligned area with its security guaranteed by the United States, the Soviet Union, and other major powers. ${ }^{44}$

Harriman wanted to assure Hanoi of a political and economic future free of Chinese domination. While the Chinese backed North Vietnam with engineering

\footnotetext{
${ }^{37}$ Harriman to Rusk, 22 September 1964, Box 519, AHP.

${ }^{38}$ Accounts of the 1963-65 deliberations include Dumbrell, Rethinking the Vietnam War, pp.50-65; Logevall, Choosing War; Schulzinger, A Time for War: The United States and Vietnam, 1941-1975 (Oxford and New York: Oxford University Press, 1997), pp.154-81.

${ }^{39}$ General review of last six months, 14 December 1968, Box 558, AHP.

${ }^{40}$ Memorandum, 12 December 1967, FRUS 1964-1968 V Vietnam 1967 (2002), pp.1105-06.

${ }^{41}$ Dumbrell, Rethinking the Vietnam War, pp.63-65.

${ }^{42}$ General review of last six months, 14 December 1968, Box 558, AHP.

${ }^{43}$ Editorial note, FRUS 1964-1968 VI Vietnam January-August 1968 (2002) , p.659.

${ }^{44}$ Draft memorandum, 1 April 1965, FRUS 1964-1968 II Vietnam January-June 1965, p.505.
} 
troops, anti-aircraft artillery troops, and military and civil material, ${ }^{45}$ there was a historic rivalry between Vietnam and China, stemming from how the Chinese had over the millennia tried to control the people on their periphery. Hanoi newspapers published articles about the heroic resistance of Vietnamese fighters to invaders from the North. ${ }^{46}$ Harriman considered that Ho Chi Minh, the leader of North Vietnam, was primarily an 'Asian Tito' rather than a communist expansionist. ${ }^{47}$ Hanoi would have a material and political interest in preserving the settlement - after his experience with Hanoi's exploitation of Laos as a transit route into South Vietnam Harriman had concluded that 'the North will never abide by any settlement unless they feel it is in their interest to do so'. ${ }^{48}$

Harriman's vision of a Vietnam pacified by regional development was not entirely novel; in a speech at Johns Hopkins University in April 1965 President Johnson said he was willing to ask Congress for a billion dollars to develop the Mekong River. The administration sponsored the creation of the Asian Development Bank in 1965, but its establishment did nothing to ease the conflict in Vietnam. There were difficulties realising the development of Southeast Asia. For a start, the region's potential for economic development would not be easy to realise, with its language differences and the absence of complementary economies. ${ }^{49}$ So far as Vietnam was concerned, Ho's suspicions of communist China can be exaggerated. A recent analysis has suggested that while Ho 'had a special affection for Vietnam's people and favoured Vietnam's unification and independence ... he firmly adhered to the Leninist principle that Communist nations should subordinate their interests to those of the international Communist movement. ${ }^{50}$

Harriman considered that communist China might be among those states supporting a non-aligned Indochina. Yet it was ideologically opportune for China to support the North Vietnamese in their war of national liberation - not least because of the developing rivalry with Moscow. ${ }^{51}$ Sino-American relations were in a frosty and rigid state with the US refusing to extend diplomatic recognition to communist China and with vituperative anti-American rhetoric emanating from Beijing. This situation clearly did not favour Chinese cooperation with the establishment and maintenance of a non-aligned Indochina. However, Harriman did recognise some of the difficulties, with him suggesting a two China policy in the UN. ${ }^{52}$ This would represent at least the beginning of a more constructive engagement, with the opportunity for a dialogue of equals. Whatever the limits of his vision, Harriman felt it essential from 1965 to try to

\footnotetext{
${ }^{45}$ Chen Jian, 'China, the Vietnam War, and the Sino-American Rapprochment', in Odd Arne Westad and Sophie Quinn Judge (eds), The Third Indochina War: Conflict between China, Vietnam and Cambodia, 1972-79 (Routledge: London and New York, Routledge, 2006), p.34.

${ }^{46}$ James G. Hershberg, Marigold: The Lost Chance for Peace in Vietnam (Stanford: Stanford University Press, 2012), p.171.

${ }^{47}$ Interview with W. Averell Harriman, conducted by Stan Karnow, 29 January 1979, WGBH Media Library \& Archives, http://openvault.wgbh.org/catalog/vietnam-e996c7-interview-with-w-averell-william-averell-harriman1979-part-2-of-4

${ }^{48}$ Memorandum for the record, 24 December 1968, FRUS 1964-1968 September 1968-January 1969 VII (2003), pp.782-83.

${ }^{49}$ Cooper to Bundy, 1 April 1965, FRUS 1964-1968 XXVII Mainland Southeast Asia; Regional Affairs (2000), p.148.

${ }^{50}$ Moyar, Triumph Forsaken, pp.9-10.

${ }^{51}$ See Lorenz M. Luthi, The Sino-Soviet Split: Cold War in the Communist World (Princeton: Princeton University Press, 2008), pp.302-39.

${ }^{52}$ Lumbers, Piercing the Bamboo Curtain, p.159.
} 
release the United States from its burgeoning and destructive involvement in Vietnam by negotiating an early exit.

\section{Ambassador at Large, Again}

Early in 1965 - in response to promptings from Harriman - Thomas Mann argued that although Harriman was 'garrulous and vain, he understands the commies and he understands power and the importance of power'. The President 'could use him ... to look around the world and come up with ideas' in relation to Vietnam. ${ }^{53}$ Soon Harriman was re-appointed to the role of Ambassador at Large (one of the positions he had occupied under JFK), with special responsibility for Vietnam. Johnson anticipated that he could 'go from capital to capital by 707 ' to investigate the possibility of negotiating an end to the war. ${ }^{54}$ Harriman was delighted at having secured the appointment, with his friend Arthur Schlesinger Jr remarking that he 'sees the Vietnam negotiation as the climax of his public career'. ${ }^{55} \mathrm{He}$ had impressive credentials for his new role. There was his success in relation to Laos in 1962, and as a State Department colleague noted, Harriman 'had been Ambassador to Moscow and to London, and besides knowing everybody in Western Europe, he also knew the diplomats of Eastern Europe as well'. ${ }^{56}$ Although the Stalin era was long gone, Harriman's name was still respected in Moscow. He was able to regale Soviet officials with stories of his meetings with Lenin and Stalin, figures who they knew only from legends and history books. ${ }^{57}$ Harriman was well versed in what was going on in Vietnam; US Ambassador in London David Bruce once noted that he spoke with 'habitual lucidity about problems in the Far East'. ${ }^{58}$ Finally, Harriman's position as a liberal was another qualification for his new post. ${ }^{59}$

The appointment was entirely a marriage of convenience for the President, given how recently he had expressed a wish to belittle Harriman. At the same time, there are doubts about whether the President took the peacemaking role seriously (it is telling that he appointed someone who he judged 'old and dead' to the role). Other than Harriman's status as the man 'in charge of peace', the mandate was imprecise, ${ }^{60}$ and - as will be seen below - the public relations dimension of the appointment was a driving concern for Johnson. ${ }^{61}$ Although an informal 'Negotiations Committee' comprising Harriman and half a dozen or so State Department officials was established, giving Harriman more status in the bureaucracy, ${ }^{62}$ he was only a rare presence at the important 'Tuesday Lunch' policy discussions. ${ }^{63}$ Perhaps more

\footnotetext{
53 Johnson-Mann telephone conversation, 25 January 1965, FRUS 1964-1968 XXXIII, pp.40-41.

${ }^{54}$ Bundy's notes of a meeting with Johnson, 7 December 1965, FRUS 1964-1968 III, p.621.

55 Arthur Schlesinger Jr., Journals 1952-2000 (London: Atlantic Books, 2007), p.249.

${ }^{56}$ John P. Leacacos, Fires in the In-Basket: The ABC's of the State Department (Cleveland and New York: World, 1968), p.304.

${ }^{57}$ Cooper, In the Shadows of History, p.238.

${ }^{58}$ Raj Roy and John W. Young (eds), Ambassador to Sixties London: The Diaries of David Bruce (Dordrecht: Republic of Letters, 2009), p.221.

${ }^{59}$ Bundy to Johnson, 1 April 1965, FRUS 1964-1968 XXVII, p.149.

${ }^{60}$ Cooper oral history interview, LBJL.

${ }^{61}$ Telephone conversation between Johnson and Harriman, 28 December 1965, FRUS 1964-1968 III, p.720.

${ }^{62}$ William Conrad Gibbon, The US Government and the Vietnam War: Executive and Legislative Roles and Relationships: Part IV: July 1965-January 1968 (Princeton: Princeton University Press, 1989), pp.388-9.

${ }^{63}$ See David C. Humphrey, 'NSC Meetings during the Johnson Presidency', Diplomatic History, 18, 1 (Winter 1994), pp. 29-45. See also David M. Barrett, Uncertain Warriors: Lyndon Johnson and his
} 
significant, though, was not Johnson's questionable commitment to Harriman's role, but Harriman's own dedication. He felt that he had been given an opportunity and he was determined to pursue it.

\section{The 'Peace Punch'}

Harriman would have his work cut out in the pursuit of peace, not least because of Hanoi's attitude. Recent studies have indicated that North Vietnamese leadership sought to fulfil what it described as the Three Aims of the Anti-American Resistance: one, the withdrawal of US forces, two, an end to the existing regime in South Vietnam, and, three, the latter's replacement with a coalition government to include pro-communist and pro-Hanoi representatives. Hanoi had little hope for a satisfactory diplomatic settlement, recalling how the talks in Geneva in 1954 had led to continued foreign involvement in Vietnam. After the US escalation in 1965 the leadership of North Vietnam was determined to preserve the revolutionary effort and to avoid negotiating an end to a war they could win without compromise on the battlefield. As such, the only diplomatic settlement that Hanoi was willing to accept amounted to an American capitulation. The North Vietnamese had Chinese support in their approach. ${ }^{64}$

Harriman saw merit in enlisting Soviet help. A US intelligence report summarised Moscow's policy as 'supplying military aid' to the North, 'playing down their own involvement, and seeking opportunities to urge the US and North Vietnamese to negotiate'. ${ }^{65}$ The latter was not much in evidence when in July 1965 managed in July 1965 to inveigle an invitation to Moscow under cover of a sightseeing visit. The idea was to engage Soviet help in the search for a settlement, but Chairman Alexei Kosygin told Harriman that the United States should talk directly to Hanoi about the possibility of a negotiated peace. ${ }^{66} \mathrm{He}$ firmly disputed Harriman's depiction of what was going on in Vietnam, leading Harriman to complain that even Stalin had not questioned his good faith. ${ }^{67}$ Generally, Kosygin was deeply impatient with the United States, having been in Hanoi at the time of the communist attack on the US base at Pleiku (about which he had no prior warning) and the subsequent US punitive strikes on North Vietnam. ${ }^{68}$ Evidence has emerged recently that after his visit to Hanoi Kosygin had visited Beijing to try to coordinate help to North Vietnam, but the discussion had been acrimonious, with the Chinese berating the Soviet Union for consorting with the Americans. The Soviets now trod especially warily in advising Hanoi to negotiate, fearing charges that they were sacrificing North Vietnamese interests while looking after their own. ${ }^{69}$

\footnotetext{
Vietnam Advisers (Lawrence: University of Kansas Press, 1993), especially pp.172-89, on the advisory system and decision-making.

${ }^{64}$ Asselin, A Bitter Peace, pp.3-4; Pierre Asselin, “”We Don’t Want a Munich”: Hanoi’s Diplomatic Strategy, 1965-1968', Diplomatic History, 36, 3 (June, 2012), pp.547-81; Pierre Asselin, 'Hanoi’s Diplomatic Struggle during the American War', in Pierre Journoud and Cécile Menétrey-Monchau (eds), Vietnam, 1968-1976: La Sortie de Guerre/Exiting a War (Brussels: Lang, 2011), pp.100-104; Jian, 'China, the Vietnam War', in Westad and Quinn Judge (eds), The Third Indochina War, p.33. ${ }^{65}$ Intelligence memorandum, 12 November 1965, FRUS 1964-1968 XIV The Soviet Union (2001), pp.338, 339.

${ }^{66}$ Embassy in Soviet Union to State Department, 15 July 1965, FRUS 1964-1968 XIV, p.308.

${ }^{67}$ Memorandum of conversation, 15 July 1965, FRUS 1964-1968 III, p.151.

${ }^{68}$ CIA memorandum, 9 April 1965, FRUS 1964-1968 XIV, p.280.

${ }^{69}$ Hershberg, Marigold, p.27.
} 
Thomas Hughes of the State Department's Intelligence and Research Bureau noted that Kosygin's essential message to Harriman was 'to urge the US in the most persuasive way to end its involvement in the Vietnam war'. ${ }^{70}$ Harriman told Chancellor Erhard of the Federal Republic of Germany that Kosygin was 'a hardened Communist and believes that Communism will be victorious ... through wars of national liberation'. ${ }^{71}$ Nevertheless he derived some satisfaction when Kosygin mentioned 'the retention of the 17th parallel'. This implied some form of recognition for South Vietnam, which previously the Soviets had resisted. ${ }^{72}$

Harriman soon made further efforts in the pursuit of peace. In August 1965, he worked with Yugoslav President Josep Tito, feeling that he 'might be induced to exert his influence on Moscow to persuade the Soviets to take greater initiative with Hanoi to come to the negotiating table' ${ }^{73}$ However, little came of any such efforts. The next of Harriman's Vietnam enterprises was more sustained, involving a diplomatic peace offensive at the end of 1965 and the beginning of 1966. Presidential aide Joe Califano suggested to Johnson 'a dramatic peace gesture', to include 'the trip of Averell Harriman to various capitals of the world'. ${ }^{74}$ At the very least, the effort would demonstrate a commitment to a negotiated settlement, and might actually bring peace. ${ }^{75}$ The President suggested to Harriman:

If you don't mind picking up your old kit bags, going to visit your old friend Tito ... see if he has any channels, go to Poland - just quietly, one of your general vacationing around, the elder statesman visiting around the world to see the state of the world, then probably get in to see that Hungarian Foreign Minister, you can go to Hungary, Poland, Yugoslavia, any place you drop in or out. ${ }^{76}$

It is clear that the 'old kit bags' initiative was as much an example of spontaneous improvisation as sustained forethought and planning. Harriman found that his flight to Poland had not even been cleared with the Polish authorities. Fortunately, the limited preparation did not stop him from seeing leaders not only in Poland but also in Yugoslavia, India, Pakistan, Iran, the United Arab Republic, Thailand, the Philippines, Australia and Japan. A number of other US officials - including VicePresident Hubert Humphrey - travelled abroad, too, while Dean Rusk made supporting efforts with foreign representatives in Washington.

To support the peace campaign the administration halted the bombing of North Vietnam. Harriman once stated that strategic bombing was of little value, with him having seen how in London during the Second World War the efforts of the Luftwaffe had bolstered rather than eroded British resolve. ${ }^{77}$ However, he also told Ambassador Bruce that maintaining the bombing in Vietnam was essential to any prospect of bringing the North Vietnamese to the negotiating table. ${ }^{78}$ As with his support of punitive attacks in Laos and Vietnam in 1964, it is clear that he was willing

\footnotetext{
${ }^{70}$ Intelligence note, 22 July 1965, FRUS 1964-1968 XIV, pp.314-15; John Dumbrell, President Lyndon Johnson and Soviet Communism (Manchester: Manchester University Press, 2004), p.107.

${ }^{71}$ Blang, Allies at Odds, p.148.

${ }^{72}$ Editorial note, FRUS 1964-1968 III, p.180.

${ }^{73}$ Harriman to Johnson, 23 December 1965, FRUS 1964-1968 III, p.687.

${ }^{74}$ Califano to Johnson, 13 December 1965, FRUS 1964-1968 III, p.638.

${ }^{75}$ Draft paper, 18 December 1965, FRUS 1964-1968 III, p.652.

${ }^{76}$ Conversation between Johnson and Harriman, 28 December 1965, FRUS 1964-1968 III, p.720.

${ }^{77}$ Abramson, Spanning the Century, p.637.

${ }^{78}$ Roy and Young (eds), Ambassador to Sixties London, p.221.
} 
to wield a big stick as well as to walk softly. The latter was evident in how Harriman felt that occasional pauses in the bombing would help to encourage the communists to come to the negotiating table by showing that the United States was willing to make concessions. However, bombing halts were less of a concession than Harriman appeared to realise. It was noted in relation to the 1965-66 pause that 'the aircraft are doing their job elsewhere, the weather is bad over North Vietnam this month anyway, reconnaissance continues over North Vietnam', and 'if no progress is made towards peace, we can catch up later in the North'. ${ }^{79}$

All the same, Harriman urged extending this pause, which had begun at the beginning of January, to the end of the Vietnamese new year, 23 January, on the grounds that 'the importance of gaining the support of governments and worldwide public opinion' outweighed any military disadvantages of extending the pause. ${ }^{80}$ Harriman was vigorous in making his case, with Bundy noting that he 'fires all his arguments at us' ${ }^{81}$ Generally, representatives of the State Department (with Rusk as a notable exception) favoured extending the pause. Undersecretary of State George Ball, for example, maintained that resuming air attacks raised the prospect of Chinese intervention. ${ }^{82}$ However, the military feared that Hanoi was stealing an advantage on the battlefield, and therefore sought to maintain the pressure on North Vietnam'. ${ }^{83}$ Finally, the advocates of a longer pause prevailed, with an extension to 31 January, even longer than Harriman had requested. By this time he felt satisfied that the communists had had enough time to respond.

Overall, Harriman had thrown his weight behind the peace offensive wholeheartedly. His verdict was that allies and neutrals now 'recognize[d] the President's sincerity' in the pursuit of peace. ${ }^{84}$ His assistant Chester Cooper had positive view, too, suggesting that Harriman's time abroad was 'the most productive of all those undertaken', ${ }^{85}$ while the US Ambassador in Tokyo suggested that his 'stopover' had brought 'psychological benefits' for American standing exceeding 'anything else we've done about Vietnam for the past year' ${ }^{86}$ At the same time, the peace offensive had obviously not brought talks with Hanoi, in part because the 'three-ring circus' publicity surrounding the campaign may have been counterproductive. ${ }^{87}$ As with the very appointment of Harriman as 'ambassador for peace', there was the question of whether the White House's initiation of the 1965-66 peace offensive was an authentic effort to foster negotiations or if its main purpose was to improve public perceptions of the Administration at home and abroad. ${ }^{88}$ It is telling that an internal document described the campaign as the 'peace punch to go

\footnotetext{
${ }^{79}$ Draft paper, 18 December 1965, FRUS 1964-1968 III, p.652; comments by Wallace J. Thies, HDiplo Roundtable review of Hershberg, Marigold, Vol. XIV, 6 (2012). www.hnet.org/ diplo/roundtables,/PDF/Roundtable-XIV-6.pdf

${ }^{80}$ Embassy in Japan to State, 8 January 1966, FRUS 1964-1968 IV Vietnam 1966 (1998), p.35.

${ }^{81}$ Note 1, FRUS 1964-1968 IV, p.34.

${ }^{82}$ Ball to Johnson, 25 January 1966, FRUS 1964-1968 IV, p.39.

${ }^{83}$ Bundy (enclosing Westmoreland message) to Johnson, 27 December 1965, FRUS 1964-1968 III, p.705.

${ }^{84}$ Memorandum of conversation, 15 January 1966, FRUS 1964-1968 IV, p.67.

${ }^{85}$ Chester L. Cooper, The Lost Crusade: The United States in Vietnam (New York: Dodd Mead, 1970), p.292.

${ }^{86}$ Johnson to Harriman, 19 January 1966, enclosing report from US Embassy Tokyo, Box 548, AHP.

${ }^{87}$ Cooper, Lost Crusade, p.296. To be fair, Harriman had himself felt that quiet diplomacy could be more effective, with him resisting another trek to Moscow on the grounds that the Soviet leadership 'might be willing to do something quietly but not otherwise'. Quoted in Dumbrell, Lyndon Johnson and Soviet Communism, p.108.

${ }^{88}$ Cooper, Lost Crusade, 292.
} 
with the military punch which is coming in January'. Johnson needed to show 'determination to move toward peace' before, as was a likelihood, the American people could be asked to make sacrifices such as increased taxes. ${ }^{89}$ The North Vietnamese had no doubt about the sincerity of the 'peace punch', rejecting it as nothing more than a 'sham'. ${ }^{90}$

\section{The Romanian Channel}

In August 1967, Harriman reflected on his recent work. The United States had 'made many efforts - directly and through third parties, public and private - to move towards a political settlement in Vietnam'. He and his colleagues had 'put forward many proposals and have instituted four bombing pauses'. In December and January 1966-67 'we were in contact with the North Vietnamese in Moscow'. ${ }^{91}$ There was no response by February, when the President sent a personal letter to Ho Chi Minh, only to receive a sharp note in reply. Ho insisted that there could be no talks unless the United States stopped the bombing and ended all reinforcements during the talks. Harriman did not mention one of the most noted of the peace initiatives, the 'Marigold' channel through Poland and Italy - presumably because much of the toing and froing was down to his staff. The Marigold channel had originated in Harriman's trip to Warsaw at the end of 1965. In an interview when he was out of office, he suggested that although Polish Foreign Minister Jerzy Michalowski 'felt that if we'd held the pause for a little longer period they [North Vietnam] might have come around', Johnson had in fact given 'ample time' with the pause, ' 37 days in all'. It seemed that 'the government in Hanoi was not ready to negotiate at that time'. ${ }^{92}$

In January-February 1967 'we were in close touch with the Wilson-Kosygin conversations' in London 'and hoped that these would produce something of value'. ${ }^{93}$ Wilson's initiative was based on exploiting Alexei Kosygin's visit to pursue the 'Phase A-Phase B' peace formula, which involved the United States ending the bombing then the North Vietnamese curtailing their infiltration of the South. Then talks would begin. ${ }^{94}$ Along with David Bruce in London, Harriman persuaded the administration in Washington to extend the bombing pause to support the London

\footnotetext{
${ }^{89}$ Draft paper, 18 December 1965, FRUS 1964-1968 III, p.652.

${ }^{90}$ Note 2, FRUS 1964-1968 IV, p.187.

${ }^{91}$ Negotiations, 16 August 1967, Special Files Public Service, JFK-LBJ, Chron File April 1968, Box 570, August 1967, AHP.

${ }^{92}$ Averell Harriman oral history interview conducted by Paige Mulhollan, 16 June 1969, LBJL. For a very comprehensive account of Marigold, see Hershberg, Marigold. Hershberg maintains that Hanoi was interested in entering into direct talks with the Americans, but because of Johnson's resumption of bombing there was a 'lost chance for peace'. Critics of the book have expressed scepticism about the prospects for peace in 1966 (talks are one thing, peace another), although it is noted that the work illuminates a variety of Cold War issues such as the Sino-Soviet relationship. See H-Diplo Roundtable Review of Hershberg, Marigold, Vol. XIV, 6 (2012), with introduction by David L. Anderson, and reviews by Robert J. McMahon, Merle Pribbenow, Wallace J. Thies, Qiang Zhai, and Hershberg's response. www.h-net.org/ diplo/roundtables,/PDF/Roundtable-XIV-6.pdf

${ }^{93}$ Negotiations, 16 August 1967, Special Files Public Service, JFK-LBJ, Chron File April 1968, Box 570, August 1967, AHP.

${ }^{94}$ On the initiative see e.g. Cooper, The Lost Crusade, pp.350-68; Jonathan Colman, A 'Special Relationship'? Harold Wilson, Lyndon B. Johnson and Anglo-American Relations 'At the Summit', 1964-1968 (Manchester: Manchester University Press, 2004), pp.122-32; John Dumbrell and Sylvia Ellis. 'British Involvement in Vietnam Peace Initiatives, 1966-1967: Marigolds, Sunflowers, and “Kosygin Week”'. Diplomatic History, 27, 1 (2003), pp.113-149.; and Geraint Hughes, 'A “missed opportunity” for Peace? Harold Wilson, British Diplomacy, and the Sunflower Initiative to end the Vietnam War, February 1967', Diplomacy and Statecraft, 14, 3 (September 2003), pp.106-130.
} 
discussions. ${ }^{95}$ Hopes crashed when hardliners (notably National Security Adviser Walt Rostow) in Washington reversed the formula at the eleventh hour, leaving Wilson, Kosygin and Bruce high and dry. Among other things, the debacle could hardly have bolstered Moscow's already qualified enthusiasm for negotiations.

Harriman was especially involved in the so-called 'Packers' channel from October 1967 to February 1968 involving the North Vietnamese and the Romanian governments. After visiting Washington at the end of September, Premier Ion Gheorghe Maurer was impressed that 'the primary US goal was to enable the South Vietnamese people to determine their own destiny and that the President desired a peaceful solution'. ${ }^{96}$ Maurer spoke along these lines to the North Vietnamese in Hanoi. With assistance from his deputy Marcovescu he also elaborated on the San Antonio formula, which Johnson had presented in September. It resembled the PhaseA-Phase B formula that the British had used earlier that year. Finally, by the end of January there was no indication that the North Vietnamese were willing to consider the San Antonio formula. ${ }^{97}$ The Romanians had, according to one analysis, 'committed high-level attention and time to the effort of December 1967-February 1968, and impressed all US officials who talked with them the accuracy of their reporting and the persistence of their efforts'. Yet the channel had its limitations. Another analysis suggested that the Romanians 'may have exaggerated the extent of their independence from the Soviets during this exercise' as Ambassador Dobrynin in Washington told Harriman that 'the Romanians always informed Moscow first of its planned moves'. ${ }^{98}$ This implied that the Soviets - perhaps chastened by the Phase A-B affair - had poured cold water on the effort.

\section{Talks about Talks}

Late in 1967 and early in 1968 there were a series of meetings in Washington in wish the advisory group known as the 'Wise Men' - establishment luminaries such as Dean Acheson, Arthur Dean and Douglas Dillon - came to doubt the possibility of victory in Vietnam and advocated an end to the war. Harriman did not participate in the 'Wise Men' meetings, but he joined them in advocating an end to the war. He pushed for moving into negotiations rapidly and urged a full bombing halt. ${ }^{99}$ The representations influenced the President. In a dramatic public address on 31 March 1968, Johnson stated that he did not seek another term in the White House, and he announced a renewed willingness to negotiate. Albeit in the context of a lengthy anti-American diatribe, Hanoi responded to the olive branch by expressing a readiness to 'send its representatives to make contact with US representatives to decide with the US side the unconditional cessation of bombing and all other war acts against the DRV

\footnotetext{
${ }^{95}$ Harriman to Johnson and Rusk, 2 February 1967, FRUS 1964-1968 V, pp.79-80.

${ }^{96}$ Editorial note, FRUS 1964-1968 V, p.1062.

${ }^{97}$ Rumanian role in Vietnam peace efforts, 1967-1968, 1 July 1969, Special Files Public Service, JFKLBJ, Vietnam General, Box 521, AHP.

${ }^{98}$ Rumanian Role in Vietnam Peace Efforts, 1967-1968, 1 July 1969, Special Files Public Service, JFK-LBJ, Vietnam General, Box 521, AHP.

${ }^{99}$ Sieg, 'W. Averell Harriman, Henry Cabot Lodge', p.242; Rostow to President Johnson, 2 November 1967, FRUS 1964-1968 V, pp.951-53; Jones to Johnson, 2 November 1967, FRUS 1964-1968 V, pp.954-971; editorial note, FRUS 1964-1968 VI, pp.457-58; notes of meeting, FRUS 1964-1968 VI, pp.471-74.
} 
[Democratic Republic of Vietnam - North Vietnam] so that talks could begin'. ${ }^{100}$ In other words, there would be talks about what would be required to set substantive discussions underway. Harriman greeted this development with enthusiasm. He considered that the domestic turmoil over Vietnam alone required an early settlement, ${ }^{101}$ and he had hopes of ending his career with a diplomatic triumph. ${ }^{102}$

However, there were those who did not consider him to be the right man for the job. Senator Fulbright felt that the administration could not be sincere about seeking peace if Harriman was in the position of the chief negotiator. ${ }^{103}$ Fulbright was probably too much influenced by Harriman's early Cold War reputation as a hardliner. Ironically, there were those who felt that Harriman was too much a dove. Walt Rostow considered, in the light of a comment from Harriman about the impact of Vietnam on the US domestic scene, that it should be left entirely to 'the President to assess at each stage, on each issue, the extent to which domestic politics plays a role if, indeed, it has a role'. ${ }^{104}$ Rostow, who had the support of General Maxwell Taylor, told Johnson that Harriman lacked 'an understanding and sympathy for the South Vietnamese'. ${ }^{105}$ It is true that the South Vietnamese had hardly inspired respect in Harriman, with him regarding the Saigon regime of President Thieu as unrepresentative and undemocratic. ${ }^{106}$ Vice-President Nguyen Cao Ky noted Harriman's disdain: 'He always looked down and consider[ed] you as one of his grandsons. Many members of the Vietnamese have trouble communicating with him'. ${ }^{107}$ To be fair, there were probably some Americans who regarded Harriman as difficult to communicate with - not least because he was inclined to turn on or off his hearing aid depending on whether he was interested in what the speaker had to say. ${ }^{108}$ He could also be somewhat haughty, but he reserved his greatest condescension for the South Vietnamese.

President Johnson was sympathetic to Rostow and Taylor's worries about too great an inclination on Harriman's part towards compromise; the US government could end up surrendering its 'present position of negotiating strength'. ${ }^{109}$ Yet dismissing Harriman from the negotiations was not to be done lightly, given his formidable stature and his tireless work since 1965. Johnson kept him in place, while Rostow used his colleague in the National Security Council William Jorden to 'keep an eye on those bastards [in Paris] and make sure that they don't give away the family jewels'. ${ }^{110}$ Harriman's critics should have been reassured by his statement in May 1968 at the beginning of the talks that the American goal was 'to preserve the right of the South Vietnamese people to determine their own future without outside

\footnotetext{
${ }^{100}$ Herbert Y. Schandler, 'The Pentagon and Peace Negotiations after March 31, 1968', in Lloyd C. Gardner and Ted Gittinger (eds), The Search for Peace in Vietnam 1964-1968 (College Station: Texas A\&M Press, 2004), pp.322, 337, 351.

${ }^{101}$ Note 3, FRUS 1964-1968 VI Vietnam January-August 1968 (2002), p.642.

102 Dumbrell, Rethinking the Vietnam War, p.98.

${ }^{103}$ Rostow to Johnson, 13 April 1968, FRUS 1964-1968 VI, p.572.

${ }^{104}$ Note 3, FRUS 1964-1968 VI Vietnam January-August 1968 (2002), p.642.

${ }^{105}$ Editorial note, FRUS 1964-1968 VI, p.530; David Milne, America's Rasputin: Walt Rostow and the Vietnam War (New York: Hill and Wang, 2008), p.224.

${ }^{106}$ Harriman memorandum, 14 December 1968, FRUS 1964-1968 VII Vietnam September 1968January 1969 (2003), p.760.

${ }^{107}$ Michael Charlton and Anthony Moncrieff, Many Reasons Why: The American Involvement in Vietnam (London: Scolar Press, 1978), p.225.

${ }^{108}$ Cooper, In the Shadows of History, p.184.

${ }^{109}$ Milne, America's Rasputin, p.225; Dumbrell, Rethinking the Vietnam War, p.98.

${ }^{110}$ Dumbrell, Rethinking the Vietnam War, p.98; Cooper, In the Shadows of History, p.275; Cooper, Lost Crusade, p.397.
} 
interference or coercion'. ${ }^{111}$ Although Harriman had no affection for Thieu, he did not have in mind the outright sacrifice of South Vietnam. Henry Kissinger noted that Harriman never 'urged or even hinted at the unilateral American withdrawal, coalition government, or unconditional ceasefire that within the year had become a staple of the Vietnam debate'. 112

\section{The Zorin Channel}

Harriman would always have a begrudging respect for the North Vietnamese. While tough negotiators, some of them were 'educated in France and had a certain French veneer or French manners'. ${ }^{113}$ However, the encounters in Paris in 1968 were the proverbial dialogue of the deaf (almost literally given Harriman's affliction). Harriman noted that at the very first meeting North Vietnamese representative, Thuy, launched into a two-hour diatribe about US crimes in Indochina. Thuy contradicted reality by maintaining that there was no North Vietnamese military presence in the South. When Harriman presented detailed evidence to the contrary, the delegation from Hanoi 'squirmed visibly'. In their very first encounter Harriman and the representatives of Hanoi 'had hit a head-on disagreement'. ${ }^{114}$ The discussions would continue to falter over the issue of reciprocity in respect of halting military action, and the question of South Vietnamese participation in substantive talks.

Harriman continued to believe that the Soviet Union could influence the North Vietnamese. He told Rusk that in the light of 'the suspicions that exist between Hanoi and Washington, we need some outside influence to assist in reaching a settlement, and there is no other that could be as effective as the Soviet Union'. ${ }^{115}$ Later, he noted how Soviet support of North Vietnam 'cost them a lot of money which was diverted from other priority programs. They feared that the war might escalate into a confrontation with them'. ${ }^{116}$ During the Paris discussions Harriman made a point of holding regular, low-key meetings with Soviet Ambassador to France, Valerian Zorin. He told Zorin that he wanted 'to have frank dealings' with him 'and others in the Soviet Embassy ... particularly as [the] American Embassy was surrounded by press' ${ }^{117}$ Moscow gave Zorin instructions to stay in touch with Harriman. ${ }^{118} \mathrm{He}$ was not alone in thinking that the Zorin channel held promise - William P. Bundy of the State Department suggested that the 'Harriman/Zorin conversation' represented 'a significant private base' for communication. ${ }^{119}$ Yet the meetings did not prove constructive, with Zorin taking every opportunity to condemn American policies. In September, Harriman noted that the Soviet diplomat had become more forthcoming and agreeable, and had conveyed the impression that the Soviet Union had pressed upon the North Vietnamese the need for a political settlement. ${ }^{120}$ However, little came

\footnotetext{
${ }^{111}$ Editorial note, FRUS 1964-1968 VI, p.659.

${ }^{112}$ Henry Kissinger, The White House Years (Boston: Little, Brown, 1979), p.258.

113 Memorandum of conversation, 16 July 1968, FRUS 1964-1968 VI, p.871.

${ }^{114}$ Embassy in France to State, 18 May 1968, FRUS 1964-1968 VI, pp.677-78.

115 Note 3, FRUS 1964-1968 VI, p.485.

${ }^{116}$ Memorandum of conversation, 10 March 1968, Special Files Public Service, JFK-LBJ, Chron File March 1968, Box 571, AHP.

${ }^{117}$ Embassy in France to State, 20 May 1968, FRUS 1964-1968 VI, p.690. Zorin was the Soviet who had come off worse in exchanges with US representative Adlai Stevenson in the UN Security Council during the Cuban Missile Crisis. Moscow had not kept him informed.

${ }^{118}$ Embassy in France to State, 25 May 1968, FRUS 1964-1968 VI, p.711.

${ }^{119}$ William Bundy to Rusk, 29 May 1968, FRUS 1964-1968 VI, p.734.

${ }^{120}$ Embassy in France to State, 3 September 1968, FRUS 1964-1968 VII, p.6.
} 
of it. In 1969 President Richard Nixon noted how Harriman, along with Ambassadors Charles Bohlen and Llewellyn Thompson, had maintained that 'the Soviet Union could do nothing as long as the United States was bombing a fellow Socialist country, and that it would be very active afterwards'. Yet even when the bombing stopped at the end of October the Soviet Union did 'nothing', other than helping to settle the protracted question of the shape of the negotiating table. ${ }^{121}$

Harriman would have been dismayed to have known that some of his colleagues made a point of concealing their own dealings with Soviet officials from him. In October, Walt Rostow, whose suspicions of Harriman remained unalloyed, wrote to Dobrynin saying that the President 'could not maintain a cessation of the bombing of North Vietnam unless it were very promptly evident to him, to the American people, and to our allies, that such an action was, indeed, a step toward peace'. It was also essential that South Vietnam should be able to participate in any substantive talks. Rostow, and Dean Rusk, considered it essential that Harriman remained ignorant of these exchanges with Dobrynin, or 'he would resign'. ${ }^{122}$ Of course, there was nothing new in what Rostow had said, but Harriman was much more disposed to ending the bombing as a means of facilitating substantive talks than was Rostow, and, as has been noted, he had less of a commitment to the regime in South Vietnam.

\section{Missed Opportunities?}

Later, a frustrated Harriman argued that there were several missed opportunities for peace in 1968. In part these missed opportunities demonstrated how the administration was split between those who like Harriman wanted to reduce military operations and those who like Rostow and Rusk were reluctant to make any concessions for fear that the communists would take military advantage. The first of Harriman's alleged opportunities occurred in June, when Alexei Kosygin wrote to Johnson to say that North Vietnam was willing to negotiate seriously for a peaceful settlement if the bombing of North Vietnam stopped. The President, Harriman and other officials met to discuss the matter. Harriman maintained that 'This is an extremely important letter... This could be a breakthrough.' He had the support of Clark Clifford, but Dean Rusk was more sceptical, pointing out that 'It would be costly to start bombing and restart it.' Similarly, Maxwell Taylor describing the letter as 'a bear trap'. ${ }^{123}$ Harriman blamed Rusk in particular for missing the chance 'to get the Soviet Government on the hook in a way that would be most valuable in future negotiations'. ${ }^{124}$ The Secretary of State had long been a target for Harriman's hostility - he once remarked that the 'crafty' and 'Machiavellian' Rusk had 'done more damage to America than anyone in our time'. ${ }^{125}$

July saw another squandered opportunity for peace, according to Harriman. Communist attacks on Saigon ceased on 18 July and the general tempo of military action declined. Harriman and his assistant Cyrus Vance took this as an indication that the North Vietnamese were providing 'the kind of restraint' the President had requested in his 31 March speech, and requested an end to the bombing. Hubert Humphrey made the same suggestion, but Johnson was not impressed, nor was Rusk.

\footnotetext{
${ }^{121}$ Editorial note, FRUS 1969-1975 Vietnam, January 1969-July 1970 (2006), p.468.

122 Rostow to Johnson, 2 October 1968, FRUS 1964-1968 VII, p.126.

123 Taylor to Johnson, 10 June 1968, FRUS 1964-1968 VI, pp.767-779.

${ }^{124}$ General review of last six months, 14 December 1968, Box 558, AHP.

125 Schlesinger Jr., Journals, p.306.
} 
The latter told Harriman that there had only been 'one or two elliptical efforts to suggest [the communists] have deescalated the fighting on the ground' and that 'we would ... be silly if we proceeded on the theory that the other side had made a political decision to deescalate the violence only to find ourselves confronted with new and major attacks which are now in prospect'. ${ }^{126}$ In Harriman's eyes, Rusk had again undermined the efforts in Paris. ${ }^{127}$

The third of the missed opportunities also took place in July. Harriman sent Vance to Washington to present the views of the negotiating team in Paris in the runup to Johnson's visit to Honolulu to confer with President Thieu of South Vietnam. Vance had also wanted to attend the conference, but did not receive an invitation. ${ }^{128}$ The conference communiqué affirmed that Saigon 'should be a full participant playing a leading role' in negotiations, which did much to buttress Thieu's stature. Thieu, who had feared sacrifice by the Americans, is said to have confided later that 'he had gotten more out of Johnson than he had dared hope for'. ${ }^{129}$ Harriman lamented the 'hard line communiqué which ... set us back again in Paris'. ${ }^{130} \mathrm{He}$ considered that Rusk, Rostow and White House adviser Abe Fortas had 'motivated the President, or put in the oar to encourage it'. ${ }^{131}$ President Thieu's attitude became especially evident a few months later. When on 31 October Johnson announced that the United States was to cease bombing and that four-party talks were imminent, Thieu said that he would not send a team to Paris. ${ }^{132}$ Thieu's self-assurance was boosted by intimations from the Nixon campaign team, who assured him that he would obtain better terms from them. Harriman was furious, urging Johnson to go ahead with the talks without Thieu. ${ }^{133}$

The last of Harriman's missed opportunities related to Vietnam as an issue in US politics. ${ }^{134}$ While on 31 March Johnson had announced his decision not to run for the Presidency and that he was taking steps towards negotiation and de-escalation in Vietnam, he was determined to stand firm, and he resented the peace faction in his party. His wrath extended to Democratic candidate Vice-President Humphrey, who wanted to see a halt to the bombing. Harriman argued that the President should have stopped the air campaign 'about three weeks before the Democratic Convention' in Chicago in August. Given the Vice-President's obvious association with the policies of the administration, ending the bombing would have helped to unify the party, with the result that 'Humphrey would have been nominated without conflict over the plank on Vietnam ... and would have started a campaign in which he would have been elected comfortably' ${ }^{135}$ In October the President was roused to fury at how Harriman and George Ball had contributed to a Humphrey speech about Vietnam. The speech was too soft for the President's liking. Harriman was 'a damned fool' who had been 'playing politics ... we can’t have people working for us that are ... breaking out to

\footnotetext{
${ }^{126}$ State to Embassy in France, 23 July 1968, FRUS 1964-1968 VI, p.888.

${ }^{127}$ General review of last six months, 14 December 1968, Box 558, AHP.

${ }^{128}$ Memorandum of conversation, 16 July 1968, FRUS 1964-1968 VI, p.871.

${ }^{129}$ Cooper, Lost Crusade, pp.399-400.

${ }^{130}$ Memorandum of conversation, 16 July 1968, FRUS 1964-1968 VI, p.871.

${ }^{131}$ General review of last six months, 14 December 1968, Box 558, AHP.

${ }^{132}$ Lien-Hang T. Nguyen, Hanoi's War: An International History of the War for Peace in Vietnam (Chapel Hill: University of North Carolina Press, 2012), p.129.

${ }^{133}$ Walter La Feber, The Deadly Bet: LBJ, Vietnam and the 1968 Election (Lanham: Rowman and Littlefield, 2005), p.164.

${ }^{134}$ For North Vietnam's analyses of the presidential race and its effects on US policy in Vietnam, see Nguyen, Hanoi’s War, pp.124-26.

${ }^{135}$ General review of last six months, 14 December 1968, Box 558, AHP.
} 
the nation speeches that neither the Secretary of State nor the President know anything about'. Johnson even considered recalling Harriman from Paris, ${ }^{136}$ but his anger soon subsided.

After Nixon's victory in November the Communists were reluctant to deal with the lame-duck Johnson White House. The first substantive meeting was held just after Johnson had left office. Harriman considered that President Thieu had 'sabotaged the talks from the very outset', with covert encouragement from the Nixon team after the November 1968 election. ${ }^{137}$ A CIA official noted that Harriman was 'frustrated and disappointed at leaving the Paris talks in such an inconclusive state'. ${ }^{138}$ Yet he did not feel that his efforts had been entirely in vain - direct talks had at least begun, and a precedent therefore established. He considered that the Nixon administration had inherited very favourable prospects for a negotiated peace, including an agreement for 'the ending of the bombing to be followed immediately by substantive peace talks between the four parties'. The United States was in a strong position 'since it had over one-half million men in South Vietnam'. However, the legacy was squandered, according to Harriman: the policy of Vietnamisation - turning the war over to the South Vietnamese while withdrawing American forces - rested on the faulty premise that 'the South Vietnamese could accomplish without 500,000 Americans what they could not accomplish without them'. ${ }^{139}$ Defenders of Nixon have noted that the South Vietnamese army managed to repulse the spring offensive of 1972, while critics have argued that US airpower was central to the victory. Generally, the South Vietnamese army was largely beyond redemption, due to inefficiency, corruption, poor morale and a lack of national identity. Furthermore, the South Vietnamese regarded the reduction of American troops and the turning over the war to them as a cop-out. ${ }^{140}$ The last American troops would leave Vietnam in 1973, and after a rapid military campaign the communists took over the entire peninsula two years later.

This article has maintained, in line with Vietnam War orthodoxy, that the Johnson administration lacked a sincere commitment to negotiation, as Averell Harriman seemed to realise in 1968. It has also been suggested that North Vietnam had little commitment to a negotiated peace, a view associated with revisionist perspectives. There is no contradiction in the idea that neither the North Vietnamese nor the American governments had a sincere commitment to negotiating an end to the war. The research on Harriman has therefore shown the limited usefulness of the orthodoxrevisionist dichotomy, as it is possible to share particular orthodox and revisionist perspectives without subscribing to either 'package deal' of arguments. It has also become apparent that while Harriman attracted the wrath of figures such as Walt Rostow, there was common ground between him and the 'hawks'. For one, his early anti-communism never waned. He believed that the ideology was an authentic threat to American security interests, not 'some other nice form of democracy which we and

\footnotetext{
136 Johnson-Rusk telephone conversation, 3 October 1968, FRUS 1964-1968 VII, pp.130-37; JohnsonRusk telephone conversation, 6 October 1968, FRUS 1964-1968 VII, pp.137-44.

${ }^{137}$ Harriman, 'Nixon’s Failure at the Paris Table', Los Angeles Times, 9 May 1972 (part II), p.9.

${ }_{138}$ Memorandum for the record, 24 December 1968, FRUS 1964-1968 VII, p.783.

${ }^{139}$ Harriman, 'Nixon's Failure at the Paris Table', Los Angeles Times, 9 May 1972 (part II), p.9.

140 Gary R. Hess, Vietnam: Explaining America’s Lost War (Oxford: Blackwell, 2009), pp.193-98.
} 
other well-meaning people can live peaceably'. ${ }^{141}$ It was essential that the United States 'stand firm in helping the people of those countries who want to protect their independence and freedom'. ${ }^{142}$ He shared the axiomatic conviction of President Johnson and others that 'From Munich until today we have learned that to yield to aggression brings only greater threats and brings even more destructive war. To stand firm is the only guarantee of a lasting peace. ${ }^{, 14}$ He never advocated a major retrenchment of US international commitments, as did some figures in Congress such as Mike Mansfield and William P. Fulbright. Furthermore, Harriman was not a dissenter along the lines of Undersecretary of State George Ball, ${ }^{144}$ who prodded Johnson to question his basic assumptions about the war.

Harriman felt that having made an initial commitment the United States should show determination to preserve South Vietnam as an independent, noncommunist state. However, the country was not worth the blood, treasure and domestic discord that it claimed, not least because the element of nationalism in the outlook of North Vietnam cast doubt on the vaunted 'domino theory'. He realised that communism in the 1960s was a diverse phenomenon, with different, and often conflicting, outlooks among communist capitals: Stalin's 'concept of the monolithic structure of international Communism has been shattered' by differing outlooks in Moscow, Havana, Belgrade and Beijing. ${ }^{145}$ The achievement of a negotiated peace became something of a personal crusade for Harriman, while figures such as Rostow, Rusk and the military continued to believe that the United States could prevail militarily. Johnson, too, often seemed to side with the 'hawks'.

As has been seen, Harriman believed firmly that 1968 represented a real opportunity for peace, but the prospect was frustrated because of intransigence in Washington. He took it for granted that the North Vietnamese had a wholehearted commitment to negotiating. However, research in Vietnamese archives suggests that his missed opportunities did not amount to much. Although the communists responded positively to President Johnson's renewed offer of talks in spring 1968, they did not want to negotiate in the conventional sense. Instead, they sought to win foreign sympathy by manipulating American and world opinion while continuing to avoid serious talks. As has been noted, for both ideological and historical reasons the Vietnamese communists considered diplomacy to be of marginal importance in their engagement with the United States and its 'puppets' in Vietnam. Hanoi had no desire to engage in substantive negotiations with the United States and had even less inclination to end the war by compromising. ${ }^{146}$ One historian has suggested that Harriman's experiences indicate that Vietnam was ‘just too complex a problem for ... traditional American cold war internationalists to tackle'. ${ }^{147}$ However, the evidence

\footnotetext{
${ }^{141}$ Harriman to Reise and Coffin, 15 October 1965, Special Files Public Service, JFK-LBJ, Chron File May 1965, Chron File October 1965, Box 568, AHP.

142 Harriman to Reiter, 22 May 1965, Special Files Public Service, JFK-LBJ, Chron File May 1965, Box 567, AHP.

${ }^{143}$ Harriman to Reise and Coffin, 15 October 1965, Special Files Public Service, JFK-LBJ, Chron File May 1965, Chron File October 1965, Box 568, AHP.

${ }^{144}$ See James A. Bill, George Ball: Behind the Scenes in US Foreign Policy (New Haven and London: Yale, 1997), and David diLeo, George Ball, Vietnam and the Rethinking of Containment (Chapel Hill: University of North Carolina Press, 1991).

${ }^{145}$ Harriman to Barnett, 11 July 1967, Special Files Public Service, JFK-LBJ, Chron File July 1967, Box 570, AHP.

146 Asselin, ‘’We Don’t Want a Munich”’, pp.547-81; Asselin, ‘Hanoi’s Diplomatic Struggle’, pp.100104.

${ }^{147}$ Sieg, 'W. Averell Harriman, Henry Cabot Lodge’, p.247.
} 
presented has indicated that the failure to achieve peace lay in large part with North Vietnam rather than with Harriman. President Johnson was probably not far off the mark when he said in May 1968 that 'There is no evidence that the North Vietnamese will negotiate seriously. They will do no more than remain in Paris to talk rather than negotiate until the next Administration takes over. ${ }^{148}$ Even then, concessions would be very hard to achieve for the Nixon administration. ${ }^{149}$

Like Nixon and Kissinger, Harriman sought an international solution to the problem of Vietnam, although he placed more emphasis on regional economic development and instead of relying on the developing Sino-Soviet split to engage communist China he looked towards Moscow. He considered that a peace agreement could 'only be reached with Moscow's help ... the Soviet Union wants a Southeast Asia non-aligned to check China's advance'. ${ }^{150}$ Moscow rued the open military struggle between the United States and North Vietnam, which threatened to undermine the post-Cuban Missile Crisis Soviet-American détente. Soviet leaders feared the conflict spreading to other areas, even developing into an East-West confrontation. ${ }^{151}$ Yet Moscow's commitment to a negotiated peace was never clearcut, given how the struggle in Vietnam was a classic war of national liberation. ${ }^{152}$ Support for North Vietnam in this context was seen as a touchstone of ideological integrity, above all in the context of the ideological rivalry with China. Ambassador Llewellyn Thompson in Moscow suggested that the Soviets 'did not want to take the blame for any settlement that would be acceptable to us, as this would greatly enhance the standing of the Chinese Communists in the whole area at their expense'. ${ }^{153}$ During the summer of 1965, Moscow responded to Chinese criticisms by emphasising to socialists across the world that the Soviet Union had recently 'undertaken a series of steps [aimed] at the intensification of aid to the Vietnamese people for the struggle against the imperialist aggressors of the US' ${ }^{154}$ From Moscow's perspective, there were even advantages to permitting the war to continue, in that the widespread opposition to US involvement in Vietnam provided opportunities for Soviet propaganda and diplomacy to undermine American influence in other areas. ${ }^{155}$ Furthermore, the war created the opportunity to test their weaponry and to examine captured American arms. ${ }^{156}$

Yet the Soviet angle had to be explored thoroughly, and Harriman - given his background dealing with Soviet officials - was just the man. He demonstrated prodigious energy and commitment in relation to trying cultivate Soviet help, and more generally, in his efforts to secure peace in Vietnam. While for Harriman, the American military engagement in Vietnam was (to paraphrase Talleyrand) a blunder

\footnotetext{
148 NSC meeting, 22 May 1968, FRUS 1964-1968 VI, p.702.

${ }^{149}$ See Larry Berman, No Peace, No Honor: Nixon, Kissinger, and Betrayal in Vietnam (New York: Simon and Schuster, 2001); Nguyen, Hanoi’s War, p.129.

${ }^{150}$ General review of the last six months, 14 December 1968, FRUS 1964-1968 VII, p.761.

${ }^{151}$ Ilya Gaiduk, The Soviet Union and the Vietnam War (Chicago: Dee, 1996), p.247.

152 Charles Dobbs, Triangles, Symbols and Constraints: The United States, the Soviet Union, and the People's Republic of China, 1963-1969 (Lanham: University Press of America, 2010), pp.116-117.

153 Quoted in Dumbrell, Rethinking the Vietnam War, p.123.

${ }^{154}$ Unofficial translation of the letter of the CPSU CC to the SED CC (undated but thought to be from July 1965), in 'Twenty- Four Soviet Bloc Documents on Vietnam and the Sino-Soviet Split, 19641966', annotated and introduced by Lorenz M. Luthi, Cold War International History Project Bulletin Issue 16 (Fall 2007/Winter 2008), p.381; http://www.wilsoncenter.org/publication/bulletin-no-16-fall2007winter-2008

155 Dumbrell, Rethinking the Vietnam War, p.129; Huizenga to Helms, 15 July 1968, FRUS 1964-1968 VI, p. 662

${ }^{156}$ Gaiduk, The Soviet Union and the Vietnam War, p.248.
} 
and not a crime, it was a blunder whose consequences he sought to mitigate by facilitating an early withdrawal on US terms. 